\title{
STRENGTHENING COMMUNITY AND BUSINESS ACTORS' \\ UNDERSTANDING ABOUT OFFICEIESS FINANCIAL SERVICES IN THE FRAMEWORK OF INCLUSIVE FINANCE POLICY DURING THE COVID-19 PANDEMIC
}

\author{
Syeni Rakhmadani \\ STISIPOL Dharma Wacana Metro, Kenanga Street No 3, Indonesia \\ syeni.rakhmadani@gmail.com
}

\begin{abstract}
With the implementation of physical distancing by the government during the Covid19 pandemic, it has had a major impact on the community and business actors in Indonesia. This situation causes a decline in the productivity and economy of the Indonesian people. However, the public and business actors should not be complacent with conditions like this. The government has issued a policy on financial inclusion in Indonesia as outlined in the Presidential Regulation of the Republic of Indonesia Number 82 of 2016 concerning the National Strategy for Financial Inclusion (SNKI). This regulation is the basis for the relevant agencies in this case the Financial Services Authority (OJK) to improve financial access for the public with the Officeless Financial Services policy in the Context of Financial Inclusion (Laku Pandai) as stipulated in OJK Regulation Number 19/POJK.03/2014 concerning Officeless Financial Services for Financial Inclusion. There are still many people who have not used and know about this program, one of which is the community in Mojopahit Village, Punggur District. The purpose of this activity is to provide a strengthening of understanding to the public and business actors regarding the Policies of Laku Pandai in the Covid-19 Pandemic Period. This service activity was carried out on June 31, 2021 in the Mojopahit Village Hall, Punggur District, Central Lampung Regency in the form of socialization and discussion. The result of this activity is the achievement of goals and benefits in community service activities.
\end{abstract}

Keywords: Laku Pandai policy, Community and business actors, Covid19 Pandemic

\section{A. Introduction}

The Covid-19 pandemic has had so many impacts on society both nationally and internationally. Indonesia as one of the affected countries also feels it both in terms of health and economic problems. The government imposes restrictions on physical distancing where daily activities such as work, study, and worship are advised to be carried out in their respective homes and the public's fear of the Covid-19 virus has an impact on decreasing productivity. According to Rakhmadani (2020), many people are afraid to carry out activities in outside the home, 
interacting with other communities

so that it directly has an impact on decreasing community productivity. The decline in community productivity makes the community's economy decline.

The government's appeal regarding physical contact restrictions has an impact on the community and business actors. In this case, the access of the public and business actors is very limited. From the community side, it is very difficult to meet their daily needs, while from the implementation of this policy, many business actors have revealed that their income has decreased until the closure of their business activities.

However, the public and business actors should not be complacent with conditions like this. There are many ways that can be taken in dealing with the implementation of this policy. One of the policies that have been issued by the government that can be used by the public and business actors to provide convenience in accessing financial services during the pandemic is officeless financial services in the context of inclusive finance or better known as smart behavior.

The presence of financial inclusion in Indonesia is stated in the Presidential Regulation of the Republic of Indonesia Number 82 of 2016 concerning the National Strategy for Financial Inclusion (SNKI). This regulation is the basis for the relevant agencies in this case the Financial Services Authority (OJK) to improve financial access for the public. As a form of its commitment to realizing the government's plan on financial inclusion, OJK initiated a program called Laku Pandai. This program is based on OJK Regulation Number 19/POJK.03/2014 concerning Officeless Financial Services in the Context of Financial Inclusion.

This program issued by OJK aims to provide banking or other financial services through collaboration with other parties (bank agents) supported by the use of information technology facilities. This program aims to provide financial products that are simple, 
easy to understand and in accordance with the needs of people who have not yet reached financial services because there are still many Indonesians who do not know, use and obtain banking services or other financial services because their residential locations are too far from the office. bank or other burdensome conditions. In addition, it also launches community economic activities so that they can encourage community economic growth, especially during the pandemic with limited community mobility.

Even though the government has made it easier for people to get banking services or other financial services. There are still many people who have not used and know about this program, one of which is the community and business actors in Mojopahit Village, Punggur District. Recognizing the low use and knowledge of the community and business actors about this program, it is important to strengthen the understanding of the community and business actors regarding the Smart Practice Policy.

The purpose of this activity is to provide a strengthening of understanding to the public and business actors about the Officeless Financial Service Program in the Context of Financial Inclusion. The final result after this activity is expected to be stronger knowledge of the community and business actors so that they are willing to use Laku Pandai

\section{B. Method of Implementation}

The method used in this service activity is through socialization of the Officeless Financial Service Program in the Context of Financial Inclusion with the aim that the community and business actors can use this service so that their daily business and needs can be met. Through this program, the team will coordinate with banking practitioners regarding the correct Laku Pandai program. Before the implementation of this activity in order to run smoothly and optimally, it is necessary to do careful preparation and planning. First, conducting field observations and analyzing the 
knowledge of the community and business actors regarding the conditions of using Laku Pandai. Then make a design/layout about the Laku Pandai Program. After that, prepare material on the Laku Pandai policy in the Covid-19 Pandemic Period. In addition, the preparation of tools and materials used in implementing the Laku Pandai Policy. Technically, the implementation of this activity is carried out by means of lectures and discussions with the community and business actors in Mojopahit Village, Punggur District, Central Lampung Regency.

\section{Result and Discussion}

This Community Service activity was carried out on Saturday, July 31, 2021 in the Mojopahit Village Hall, Punggur District, Central Lampung Regency which was attended by 20 Participants consisting of Village officials, Local Community and Business.

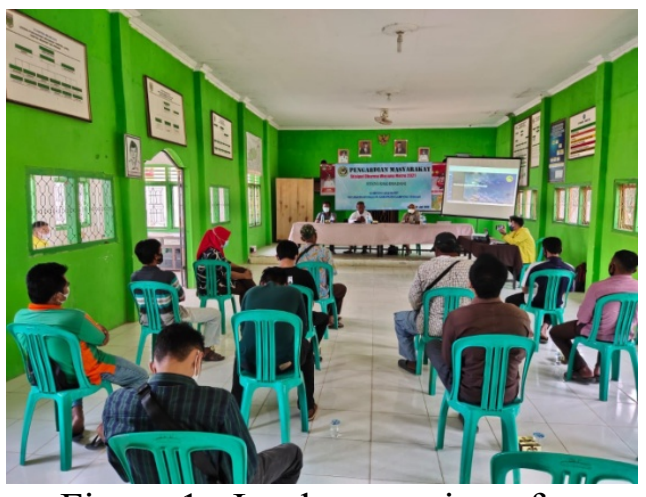

.Figure $1:$ Implementation of Community Service Activity

This Community Service activity was carried out in the form of socialization and discussion with the material presented, namely strengthening the understanding of the community and business actors regarding officeless financial service policies in the context of financial inclusion during the Covid-19 pandemic. The implementation of this activity is intended to strengthen public knowledge related to the Officeless Financial Service Policy in the Context of Financial Inclusion in the Covid-19 Pandemic Period. Submission of material was carried out by Syeni Rakhmadani, S.A.N., M.Si with several materials presented, including: 


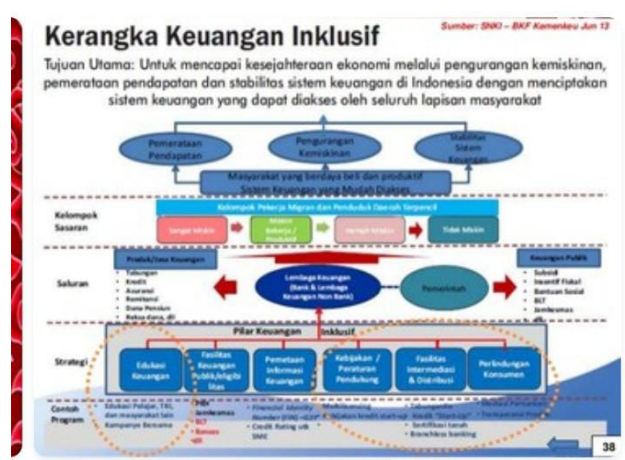

Figure 2. Point Slides for Socialization Materials

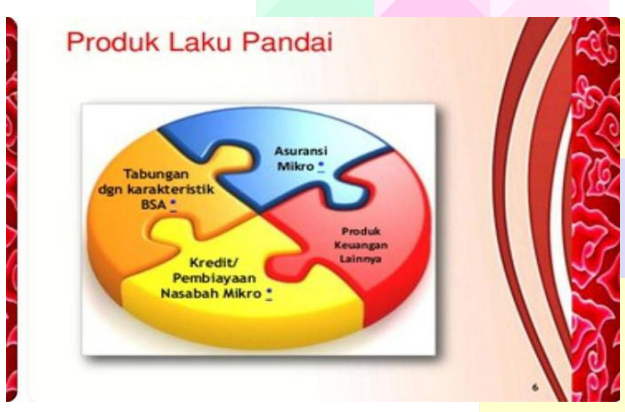

Figure 3. Point Slides for

Socialization Materials

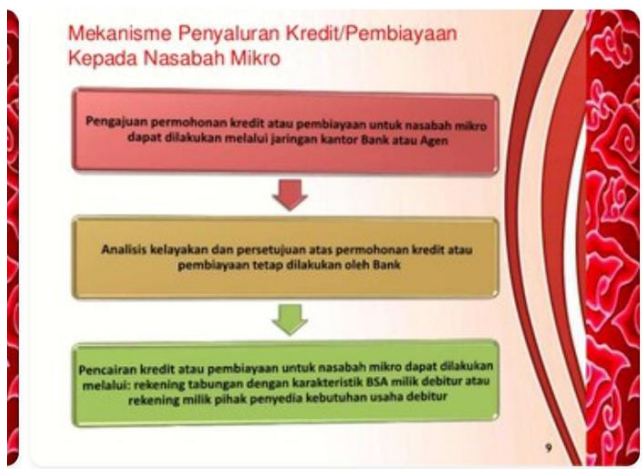

Figure 4. Point Slides for Socialization Materials

Based on the Conceptual

Framework with the phenomenon that occurs regarding Officeless Financial Services in the Context of Financial Inclusion, in this case the role of the banking industry and other financial services industries is very important in supporting economic activities and growth in Indonesia during the Covid19 pandemic. In the latest developments, each industry is required to improve and expand access to financial services, in order to provide more benefits to all levels of Indonesian society, especially to people affected by Covid-19 who are not familiar with, use, and/or obtain banking services and services. other finance.

Expanding access to financial services is absolutely necessary for all levels of society with low incomes and those living in remote areas. With more inclusive financial services, it is hoped that it will have an impact on more and more parties involved besides the government and the private sector but also the community, which can encourage economic growth so that inequality in economic problems that occur during the limitation of physical contact in the community during the Covid-19 pandemic can be resolved.

Realizing the importance of Financial Inclusiveness, the 
government together with relevant stakeholders including the financial industry have actually prepared the National Strategy for Financial Inclusion (SNKI) which was published in June 2012 and refined in June 2013. The National Strategy for Financial Inclusion has 6 (six) pillars, namely: a. financial education; b. public financial facilities; c. mapping of financial information; d. supporting policies or regulations; e. intermediation and distribution facilities; and f. consumer protection.

One of the programs in the SNKI pillar regarding intermediation and distribution facilities is the provision of branchless financial services, which can be done, among other things, through Officeless Financial Services in the Context of Financial Inclusion (Laku Pandai). Through Laku Pandai, Financial Services Institutions play an important role in supporting SNKI in order to realize financial inclusion

Laku Pandai itself utilizes information technology facilities such as cellular phones, Electronic Data Capture (EDC) and/or internet banking that supports financial services by the Bank through agents, which are expected to reach people in remote areas. By utilizing these information technology facilities, it is also expected to reduce the costs associated with conducting financial transactions, so that it can become cheaper for the community. In addition, Laku Pandai also provides financial products that are tailored to the needs of people in remote areas and/or low incomes, with simple characteristics so that they are easier to understand, accompanied by ease of processing application documents from prospective customers. With increased knowledge and understanding of financial services, it is hoped that it will help increase public awareness about the importance of financial management during the Covid-19 pandemic. Better financial management can increase people's income and welfare. If this awareness is increasingly widespread and strengthened in every level of society, it will support the realization of Financial Inclusion in Indonesia.

\section{Conclusion}

After this Community Service Activity has been carried out, conclusions can be drawn: 1) During 
the socialization and discussion, Participants participate from the beginning to the end of the event; 2) Participants were very enthusiastic during the discussion because of the suitability of the material with the phenomena that occurred; and 3) Participants gain a strengthened understanding of Officeless Financial Services in the Context of Financial Inclusion.

\section{REFERENCES}

Rakhmadani, Syeni. (2020). Knowledge Improvement of New Habits Adaptation towards a Productive Society and Safe Covid-19. PICS-J : Pasundan International Community Service Journal 2, 91-97.

Sastiono, P \& Nuryakin, C. (2019). Commentary: Inklusi Keuangan Melalui Program Layanan Keuangan Digital dan Laku Pandai. Jurnal Ekonomi dan Pengembangan Indonesia, doi:https//doi.org/110.21002/jepi. v119i2.1228

Wardhana, Yuditya. (2020). Socialization of policy alternative models in effots of handle COVID-19 pandemic problems in yosorejo village, Metro City. PICS-J : Pasundan International Community Service Journal 2, 9197.

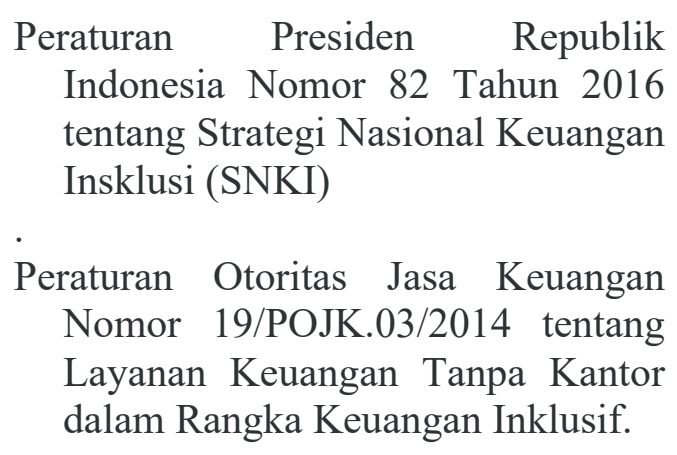

Peraturan Presiden Republik Indonesia Nomor 82 Tahun 2016 tentang Strategi Nasional Keuangan Insklusi (SNKI)

Peraturan Otoritas Jasa Keuangan Nomor 19/POJK.03/2014 tentang Layanan Keuangan Tanpa Kantor dalam Rangka Keuangan Inklusif. 